Article

\title{
Growth Performance and Characterization of Meat Quality of Broiler Chickens Supplemented with Betaine and Antioxidants under Cyclic Heat Stress
}

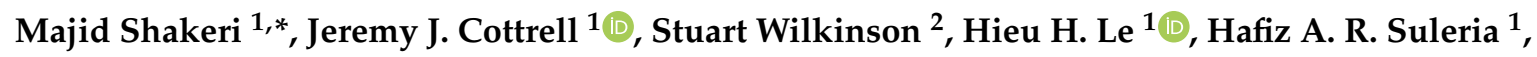 \\ Robyn D. Warner ${ }^{1}$ and Frank R. Dunshea ${ }^{1}$ (D) \\ 1 Faculty of Veterinary and Agricultural Sciences, The University of Melbourne, Parkville, VIC 3010, Australia \\ 2 Feedworks Pty Ltd., Romsey, VIC 3434, Australia \\ * Correspondence: mshakeri@student.unimelb.edu.au; Tel.: +61-424-899-235
}

Received: 30 June 2019; Accepted: 19 August 2019; Published: 22 August 2019

\begin{abstract}
Heat stress (HS) causes oxidative stress, which compromises broiler performance and meat quality. The aim of this study was to determine whether dietary antioxidants could be used as an amelioration strategy. Seventy-two day-old-male Ross-308 chicks were exposed to either thermoneutral or cyclical heat stress conditions. Diets were either control commercial diet (CON), CON plus betaine (BET), or with a combination of betaine, selenized yeast, and vitamin E (BET + AOX). Heat stress increased the rectal temperature $(p<0.001)$, respiration rate $(p<0.001)$, decreased blood $\mathrm{pCO}_{2}(p=0.002)$, and increased blood $\mathrm{pH}(p=0.02)$, which indicated the HS broilers had respiratory alkalosis. Final body weight was decreased by HS $(p<0.001)$, whereas it was improved with BET $(p=0.05)$. Heat stress reduced cooking loss $(p=0.007)$ and no effect on drip loss, while BET decreased the drip loss $(p=0.01)$. Heat stress reduced the myofibril fragmentation index $(p<0.001)$ and increased thiobarbituric acid reactive substances $(p<0.001)$, while these were improved with the combination of BET $+\operatorname{AOX}(p=0.003)$. In conclusion, BET overall improved growth rates and product quality in this small university study, whereas some additional benefits were provided by AOX on product quality in both TN and HS broilers.
\end{abstract}

Keywords: heat stress; betaine; antioxidants; growth performance; meat quality; broiler chickens

\section{Introduction}

The management of heat stress (HS) is a subject of increasing concern for industry with increasing global temperatures and incidence of sub-tropical and tropical broiler production [1]. Broilers are susceptible to increased environmental heat loads for a variety of reasons, including that they lack sweat glands, feather coverage, and that increased selection for muscling means they are comparatively less resilient to heat than other production animals [2]. Broilers that are reared under hot conditions have a reduced growth rate, in part due reduced feed intake. However, only half of the consequential reduction in growth rates is due to feed intake alone [3], and skeletal muscle from thermally challenged broilers has reduced rates of protein synthesis and to a lesser extend proteolysis [4]. This is, in part, due to adaptive endocrine alterations to HS, for example, thyroid hormones are permissive for growth and negatively correlated with elevated temperature. Furthermore, insulin is an important regulator of muscle metabolism and protein synthesis, and the downstream anabolic and metabolic pathways of insulin signaling are suppressed in the skeletal muscle of the HS broiler [5]. Other implications for product quality include reduced muscle glycogen and muscle $\mathrm{pH}$, paler colour [6], increased lipid oxidation [7], and changes muscle fiber structure [8,9]. Consequently, there is a growing interest in affordable dietary strategies to reduce the adverse effects of HS on meat quality and performance in 
domestic animals $[10,11]$. Some of the most promising strategies include betaine (BET), selenium (Se), and vitamin E (VitE), which have individually shown positive effects on chicken performance and meat quality during HS.

Betaine is a natural compound that can be found in many organisms and it is commercially derived from sugar beets. It protects cells against osmotic inactivation, increases water retention of cells [12], and improves protein and energy metabolism [13] by acting as a methyl donor, which is important for the synthesis of methionine and carnitine. Betaine is a potent antioxidant [14] and dietary BET can increase plasma glutathione peroxidase in chickens under both thermoneutral (TN) and HS conditions [15]. It also reduces the core body temperature by reducing the activity of the ion pumps that are required for osmoregulation, allowing more energy for growth [16-18]. In this regard, BET may improve body weight and meat quality in chickens $[19,20]$. Selenium is an antioxidant that may affect growth performance by the maintenance of tissue cellular integrity $[21,22]$. The activity of Se is often augmented through interactions with VitE, which maximizes the efficiency of the vitamin as an antioxidant. There are indications that Se deficiency has deleterious effects on growth performance and meat quality $[23,24]$. Moreover, VitE improves performance and meat quality by protecting and regenerating damaged tissues during oxidative stress $[25,26]$ and reducing lipid peroxidation and drip loss [27].

In a previous investigation on the individual and combined effects of BET and the antioxidants Se and VitE (AOX) on growth performance and physiological response to HS we observed improved performance in response to BET alone, and no positive effects of AOX [15]. However, we did see some additional benefits of AOX when combined with BET. Therefore, the aims of the present study were to investigate the effects of BET alone and in combination with Se and VitE on the growth performance and meat quality characterization and the physiological responses to HS in broiler chickens.

\section{Materials and Methods}

\subsection{Ethics Statement}

The study was performed in Animal facility approved by the Animal Ethics Committee of the Faculty of Veterinary and Agricultural Sciences, The University of Melbourne, Australia (Protocol no. 1714224.1). The use of animals for research is regulated by federal and state legislation, according to the Prevention of Cruelty to Animals Act 1986 and the Prevention of Cruelty to Animals Regulations 2008.

\subsection{Animals, Diet and Experimental Design}

Seventy-two one day-old male Ross-308 chicks were obtained from a commercial hatchery and transported at $\sim 30^{\circ} \mathrm{C}$ within $2 \mathrm{~h}$ distance to our facility (Tri Foods Pty. Ltd., Bannockburn, Victoria, Australia). The chicks were randomly selected, wing-tagged, and individually weighed and housed in pens of three chicks in one of two environmentally controlled rooms (12 pens/room). The temperature for both rooms was held constant at $33^{\circ} \mathrm{C}$ for the first seven days of the study before being gradually decreased to $25^{\circ} \mathrm{C}$ from days 7 to 21 for the $\mathrm{TN}$ room $\left(1{ }^{\circ} \mathrm{C}\right.$ decrease every two days), and then remained at $25^{\circ} \mathrm{C}$ from days 21 to 42 [28]; or, cyclic HS conditions where the temperature was kept at $33^{\circ} \mathrm{C}$ from days 7 to 42 between 9 am and $5 \mathrm{pm}$ and at the prevailing temperature in the TN room from $5 \mathrm{pm}$ until $9 \mathrm{am}$. The relative humidity was between 45-60\% during the study. Light was provided $24 \mathrm{~h}$ for the first three days after placement and it was gradually reduced $(1 \mathrm{~h} /$ day $)$ to $20 \mathrm{~h}$ at day 7 for both rooms. The pens measured $1 \mathrm{~m} \times 1 \mathrm{~m}$ and they had $\sim 10 \mathrm{~cm}$ deep wood shavings on the floor.

The chickens were fed either a commercial control diet (50 IU $/ \mathrm{kg}$ VitE and $0.3 \mathrm{mg} / \mathrm{kg} \mathrm{Se}$ ) (CON), or the control diet supplemented with $1 \mathrm{~g} / \mathrm{kg}$ betaine (Betafin S1, DuPont, Marlborough, UK) (BET) or the control diet plus a combination of $1 \mathrm{~g} / \mathrm{kg}$ betaine with $0.3 \mathrm{mg} / \mathrm{kg}$ Se (selenised yeast, selenoSource 3,000, Diamond V Mills, Cedar Rapids, IO, USA) and 200 IU/kg natural yeast VitE (VE 200, dl- $\alpha$-tocopheryl acetate, ADM, Chicago, IL, USA) (BET + AOX). The control diet was formulated to satisfy the NRC [29] requirements with Se provided as selenised yeast and the VitE as natural VitE, as outlined above. Feed 
(Feedworks BESTMIX, The University of Sydney, Sydney, Australia) was formulated as a commercial starter from days 1 to 14 (CP $24.7 \%$ and $12.6 \mathrm{MJ} \mathrm{ME} / \mathrm{kg}$ ), grower from days 15-28 (CP $22.8 \%$ and 13.0 MJ ME/kg) and finisher from days 29-42 (CP $21.24 \%$ and 13.4 MJ ME/kg). Feed and water were provided ad libitum. Live weight and consumed feed were recorded weekly to calculate the average daily body weight gain (ADG), average daily feed intake (ADFI), and feed conversion ratio (FCR).

Starting from day 14, two chickens per pen were randomly selected weekly to measure rectal temperature at $8 \mathrm{am}, 12 \mathrm{pm}$, and 15 pm with a digital thermometer (Comark PDT 300, Norwich, Norfolk, UK) inserted about $3-4 \mathrm{~cm}$ into the rectum for $30 \mathrm{sec}$. The respiration rate was measured from two randomly selected chickens per pen at $12 \mathrm{pm}$ on days 35 and 41 . Chickens were filmed with a cellphone (iPhone 7, Apple Inc., Cupertino, CA, USA) and then the number of breaths taken over a $20 \mathrm{sec}$. period was quantified and then expressed as breaths per minute.

Twenty-four chickens were randomly selected to collect blood samples (four from each treatment) on day 41. Approximately $3 \mathrm{~mL}$ blood was collected from the wing vein and centrifuged at $10,000 \times g$ for 15 min to obtain plasma. A portion $(\sim 0.3 \mathrm{~mL})$ of the fresh blood sample was loaded into an automatic blood gas analysis (EPOC ${ }^{\circledR}$; Alere, Waltham, MA, USA) to measure blood gas and chemistry parameters.

\subsection{Slaughter and Meat Quality Measures}

All of the chickens were killed with a dry electrical stunner (standard 15 amp 220-volt, Mitchell Engineering Food Equipment, Pty Ltd., Clontarf, Queensland, Australia). Subsequently, the chickens were immersed in hot water of $60-62^{\circ} \mathrm{C}$ for $80 \mathrm{~s}$. before they were mechanically stripped of the feathers (1.5 Kw, 660 mm, Bellsouth Poultry Equipment, Pty Ltd., Dandenong, South Victoria, Australia). All of the carcasses were then placed in sealable plastic bags and sealed before being suspended in ice water $\left(\sim 4{ }^{\circ} \mathrm{C}\right)$ for $40 \mathrm{~min}$ and the carcasses were then transferred to a cool room $\left(4^{\circ} \mathrm{C}\right)$. These slaughter procedures follow standard industry practice. The $m$. Pectoralis major and minor, hereon referred to as the breast muscle, were removed from the carcass at $24 \mathrm{~h}$ after slaughter.

Muscle pH was measured with a polypropylene spear type electrode (Ionode IJ44A, Pty Ltd., Tennyson Queensland, Australia), calibrated at pH 4 and 7 and portable $\mathrm{pH}$ meter (WP-80M, TPS, Pty Ltd., Brendale, Queensland, Australia) by inserting $2 \mathrm{~cm}$ deep for $30 \mathrm{~s}$. Immediately after the removal of the feathers, the breast muscles were partially skinned and $\mathrm{pH}$ measured three times at $>10$ min., $1 \mathrm{~h}$ and $24 \mathrm{~h}$ after slaughter before deboning. Drip loss was quantified by weighing $10 \mathrm{~g}$ of breast meat and then suspending in a bottle with a sealed cap for $48 \mathrm{~h}$. All of the samples had freshly trimmed surfaces and they were devoid of covering fat or connective tissue. After $48 \mathrm{~h}$, all of the samples were re-weighed to calculate drip loss. Warner Bratzler shear force (WBSF) was quantified on blocks of cooked meat $1 \mathrm{~cm}$ wide, $1 \mathrm{~cm}$ high, and $3 \mathrm{~cm}$ lengthwise (Instron, canton, MA, USA). Prior to cooking, samples $(80 \mathrm{~g})$ were weighed and were then placed in a plastic bag and then cooked in an $80{ }^{\circ} \mathrm{C}$ water bath for $40 \mathrm{~min}$. After cooking, the samples were cooled in running tap water for $10 \mathrm{~min}$. , and then gently dried with a piece of paper towel without being squeezed to remove all moisture lost on the meat surface before they were re-weighed to measure cooking loss. The cooked samples were chilled overnight at $4{ }^{\circ} \mathrm{C}$ to measure WBSF after $24 \mathrm{~h}$. Cooked samples were cut into blocks and WBSF was measured using an inverted V-blade and cross head speed $200 \mathrm{~mm} / \mathrm{min}$. perpendicular to muscle fiber orientation and Lloyd (Lloyd Instruments LS5S/C Materials testing instrument, Lloyd Instruments Ltd., Hampshire, UK) texture analyser fitted with a $500 \mathrm{~N}$ load cell. Warner Bratzler shear force was performed at least six times for each sample. A Minolta chromameter CR-400 with $8 \mathrm{~mm}$ aperture (Minolta Pty Ltd., Tokyo Japan, light source D65, observer angle $2^{\circ}$ ) was used to determine the colour at days 1 and 4 post-slaughter after a $20 \mathrm{~min}$. bloom at $4{ }^{\circ} \mathrm{C}$ with measurements in the $\mathrm{CIE} \mathrm{L}^{*}, \mathrm{a}^{*}, \mathrm{~b}^{*}$ system where $L^{*}$ indicates relative lightness, $a^{*}$ redness and $b^{*}$ yellowness. Breast muscle was placed on retail trays, over-wrapped, and then placed in simulated retail display, with illumination, at $4{ }^{\circ} \mathrm{C}$ for three days before measuring colour. All of the readings were taken in triplicate and averaged.

The method of [30], as modified by [31], was used with some modifications to measure myofibrillar fragmentation index (MFI). Briefly, $2 \mathrm{~g}$ minced breast meat was added to $20 \mathrm{~mL}$ MFI buffer (100 mM 
$\mathrm{KCl}, 20 \mathrm{mM}$ potassium phosphate (pH 7), $1 \mathrm{mM}$ EGTA, $1 \mathrm{mM} \mathrm{MgCl}_{2}$, and $1 \mathrm{mM} \mathrm{NaN}$ ) and then homogenized for $30 \mathrm{~s}$. at 10,000× $g$ (IKA Ultra Turrax ${ }^{\circledR}$ T 25 digital, Rawang, Selangor, Malaysia). All samples were kept in crushed ice during homogenizing. Samples were centrifuged at $100 \times g$ for $15 \mathrm{~min}$. at $2{ }^{\circ} \mathrm{C}$. After centrifuging, supernatants were discarded and $20 \mathrm{~mL}$ MFI buffer was added to each tube. Once more, the samples were centrifuged for another $15 \mathrm{~min}$., at $100 \times g$ at $2{ }^{\circ} \mathrm{C}$. Subsequently, the supernatant and fat cap were discarded. $10 \mathrm{~mL}$ MFI was added to each tube and vortexed until well mixed. Samples were filtered through a polyethylene cell strainer $(100 \mu \mathrm{m})$. Protein assay was done by adding $0.25 \mathrm{~mL}$ suspension with $0.75 \mathrm{~mL}$ MFI buffer and $4 \mathrm{~mL}$ biuret reagent $\left(1.5 \mathrm{~g} \mathrm{CuSO}_{4} \cdot 5 \mathrm{H}_{2} \mathrm{O}, 6 \mathrm{~g}\right.$ $\mathrm{NaKC}_{4} \mathrm{H}_{4} \mathrm{O}_{6} \cdot 4 \mathrm{H}_{2} \mathrm{O}, 300 \mathrm{~mL} \mathrm{10 \%} \mathrm{NaOH}$ adding to $700 \mathrm{~mL} \mathrm{dH}_{2} \mathrm{O}$ ). The mixture was kept in a dark place at room temperature for $30 \mathrm{~min}$. Simultaneously, bovin serum albumin was prepared as $0,2.5,5,7.5$, and $10 \mathrm{mg} / \mathrm{mL}$. The absorbance of prepared standards was read at $540 \mathrm{nM}$ with a spectrophotometer (UV-1800, Shimadzu, Kyoto, Japan). The myofibril protein concentration of the samples was adjusted to $0.5 \mathrm{mg} / \mathrm{mL}$ and then all of the prepared samples were vortexed and mixed well prior to reading absorbance with spectrophotometer at $540 \mathrm{nM}$ (UV-1800, Shimadzu, Kyoto, Japan).

Thiobarbituric acid reactive substances (TBARS) were measured as per [32], with minor modifications. To determine TBARS, $2 \mathrm{~g}$ of breast muscles were homogenized in $8 \mathrm{~mL}$ potassium chloride with homogenizer (IKA Ultra Turrax ${ }^{\circledR}$ T 25 digital, Rawang, Selangor, Malaysia) for 30 s. at 10,000 $\mathrm{g}$. Afterwards, $200 \mu \mathrm{L}$ of homogenized samples was mixed with $35 \mu \mathrm{L}$ butylated hydroxy toluene $7.0 \mathrm{mM}$, $165 \mu \mathrm{L} 8.1 \%$ sodium dodecyl sulphate, $2 \mathrm{~mL}$ thiobarbituric acid $0.8 \%$, topped up with $300 \mu \mathrm{L}$ distilled water. Subsequently, the mixture was heated at $95{ }^{\circ} \mathrm{C}$ for $60 \mathrm{~min}$. The mixture was cooled under running water for $5 \mathrm{~min}$., and $3 \mathrm{~mL} \mathrm{n}$-butyl alcohol was added into the mixture, and then vortexed for $60 \mathrm{~s}$. The mixture was centrifuged at $3000 \times g$ for $10 \mathrm{~min}$. and the supernatant $A_{532}$ quantified vs a malondialdehyde (MDA) (mg/kg) standard curve (UV-1800, Shimadzu, Kyoto, Japan).

\subsection{High Performance Liqiud Chromatography Analysis of Betaine and Derivatives}

Betaine concentrations were determined in liver, muscle, and plasma samples. Standards and samples were prepared while using the method of [33], with some modifications. The frozen tissue samples were first pulverized in a dry mill pre-cooled in liquid nitrogen (The Cellcrusher, Cork, Ireland). Pulverized tissue $(0.5 \mathrm{~g})$ was homogenized with homogenizer (IKA Ultra Turrax ${ }^{\circledR} \mathrm{T} 25$ digital, Rawang, Selangor, Malaysia) for $1 \mathrm{~min}$. at 10,000 $\mathrm{g}$ in $5 \mathrm{~mL}$ tris buffer $(1 \mathrm{M}, \mathrm{pH}$ 7), centrifuged at $14,000 \times g$ for $20 \mathrm{~min}$., and the supernatant was then collected. The supernatant and plasma samples $(50 \mu \mathrm{L})$ was added to $50 \mu \mathrm{L}$ of $100 \mathrm{mmol} / \mathrm{L}$ monopotassium phosphate and $900 \mu \mathrm{L}$ derivatization solution containing $50 \mathrm{mmol} / \mathrm{L}$ 4-bromophenacyl bromide and $2.5 \mathrm{mmol} / \mathrm{L} 18$-crown-6 in acetonitrile and vortex mixed. The samples were heated to $80^{\circ} \mathrm{C}$ in a block heater for $1 \mathrm{~h}$, cooled to room temperature before filtering through a $0.22 \mu \mathrm{m}$ filter into a glass High Performance Liquid Chromatography (HPLC) vial, and then placed on a wisp model 712 autosampler attached to a HPLC. The HPLC (Waters 2998, Milford, MA, USA), comprising a quaternary pump, vacuum degasser, an autosampler, and a column compartment with thermostat and a photodiode array (PDA) detector, with data acquisition from Empower software (Water, Milford, MA, USA). A XBrigge columns (HILIC $3.5 \mu \mathrm{m}, 4.6 \times 150 \mathrm{~mm}$, Waters, Milford, MA, USA) was used, with the temperature being maintained at $25^{\circ} \mathrm{C}$. An isocratic mobile phase solution contained $22 \mathrm{mmol} / \mathrm{L}$ choline chloride (Sigma-Aldrich, St. Louis, MI, USA) in $900 \mathrm{~mL} / \mathrm{L}$ acetonitrile and $100 \mathrm{~mL} / \mathrm{L}$ distilled water were used at a flow rate of $1.0 \mathrm{~mL} / \mathrm{min}$. The mobile phases were filtered by using a $0.45 \mu \mathrm{m}$ filter and then degassed by sonication for $30 \mathrm{~min}$. before use. The injection volume for the analysis of all samples was $10 \mu \mathrm{L}$. The UV detection was set to monitor the analytes at $254 \mathrm{~nm}$.

\subsection{Plasma Thyroid Hormone Analysis}

The thyroid hormones were measured and validated by using free triiodothyronine $\left(\mathrm{T}_{3}\right)$ and Thyroxine $\left(\mathrm{T}_{4}\right)$ radioimmunoassay kit in plasma (MP Biomedicals, LLC Diagnostics Division, Fountain Parkway, Solon, $\mathrm{OH}, \mathrm{USA}$ ). For both $\mathrm{T}_{3}$ and $\mathrm{T}_{4}$, plasma samples were kept at room temperature before use in order 
to minimise deterioration. For $\mathrm{T}_{3}, 100 \mu \mathrm{L}$ of standards and samples were added to each tube. Then, $1 \mathrm{~mL}$ free $\mathrm{T}_{3}$ tracer was added to each tube and vortexed for 3-5 s. before being incubated in a water bath for $150 \mathrm{~min}$. at $37^{\circ} \mathrm{C}$. After incubating, the liquid was aspirated or decanted from all tubes. Added $1 \mathrm{~mL}$ distilled water to each tube and aspirated again. All of the tubes were read with a gamma counter (PerkinElmer Life Science, Wallac 1470 Wizard gamma counter, Waltham, MA, USA). The obtained results were calculated based on the structure that was provided by the company and the results are presented as $\mathrm{pg} / \mathrm{mL}$ for $\mathrm{T}_{3}$. All of the procedures were the same for $\mathrm{T}_{4}$, except $50 \mu \mathrm{L}$ of standards and samples were used, the incubation time was $90 \mathrm{~min}$., and the results were presented as $\mathrm{ng} / \mathrm{dL}$.

\subsection{Statistical Analyses}

All of the data were analysed while using ANOVA for the main and interactive effects of temperature, pooled BET (Control vs BET and BET + AOX), and within BET (BET vs BET + AOX) using GenStat version $16^{\text {th }}$ (VSNi Ltd., Hemel Hempstead, UK). These planned contrasts allows for the separation of the response to BET as well as any additional responses to AOX [34]. For physiological parameters and meat $\mathrm{pH}$ and color data the effects of main and interactive effects of time were also included as repeated measures effects in the residual maximum likelihood model. These data were separately analysed due to the large increase in the magnitude and variation in TBARS between $0.5 \mathrm{~h}$ and $24 \mathrm{~h}$ post slaughter. Differences were considered a trend when $0.10>p>0.05$ and significant when $p<0.05$.

\section{Results}

\subsection{Growth Performance}

From days 1-21, there were no effects of temperature or dietary treatments on average daily gain (ADG), average daily feed intake (ADFI), and feed conversion ratio (FCR) (Table 1). Between days 21 and 42, there was a reduction in ADG (96.7 vs $85.9 \mathrm{~g} / \mathrm{d}, p<0.001)$ and ADFI (188 vs $172 \mathrm{~g} / \mathrm{d}, p=0.017$ ), but no effect on FCR in response to HS. BET tended to increase ADG between days 21 and 42 (88.3 vs $92.9 \mathrm{~g} / \mathrm{d}, p=0.10)$, but it had no effect on ADFI or FCR. Over the duration of the entire study there was a reduction in ADG (72.0 vs $65.4 \mathrm{~g} / \mathrm{d}, p<0.001)$ and ADFI (128 vs $118 \mathrm{~g} / \mathrm{d}, p=0.033$ ) but no effect on FCR in response to HS. BET tended to increase ADG over the entire study $(66.4 \mathrm{vs} 69.9 \mathrm{~g} / \mathrm{d}, p=0.056)$ but had no effect on ADFI or FCR. As expected from the growth performance data, HS reduced final weight (3065 vs $2783 \mathrm{~g}, p<0.001$ ) and breast weight (737 vs $633 \mathrm{~g}, p<0.001)$. Dietary BET increased final weight (2825 vs $2974 \mathrm{~g}, p=0.052)$ and breast weight (634 vs $710 \mathrm{~g}, p<0.002)$. There were no within BET effects of AOX of growth performance or final and breast weight, which indicated that there were no additional or negative effects of additional supplementation with AOX nor were there any significant interactions.

Table 1. Effect of dietary betaine (BET) and antioxidants (AOX) on average daily gain (ADG), average daily feed intake (ADFI), and feed conversion ratio (FCR), and carcass characteristics during thermoneutral (TN) and heat stress (HS) conditions.

\begin{tabular}{|c|c|c|c|c|c|c|c|c|c|c|}
\hline \multirow{2}{*}{$\begin{array}{c}\text { Temperature (T) } \\
\text { Diet }\end{array}$} & \multicolumn{3}{|c|}{ Thermoneutral } & \multicolumn{3}{|c|}{ Heat Stress } & \multirow{2}{*}{ s.e.d. ${ }^{2}$} & \multicolumn{3}{|c|}{$p$-Value ${ }^{3}$} \\
\hline & $\mathrm{CON}^{1}$ & BET & BET + AOX & $\mathrm{CON}^{1}$ & BET & BET + AOX & & $T$ & BET & $\begin{array}{c}\text { Within } \\
\text { BET }\end{array}$ \\
\hline Day 0-21 & & & & & & & & & & \\
\hline $\mathrm{ADG}, \mathrm{g} / \mathrm{d}$ & 45.5 & 47.0 & 49.5 & 43.4 & 44.1 & 46.8 & 1.85 & 0.11 & 0.15 & 0.17 \\
\hline ADFI, g/d & 70.8 & 64.3 & 67.3 & 59.7 & 67.9 & 66.3 & 4.35 & 0.50 & 0.88 & 0.87 \\
\hline FCR, g/g & 1.56 & 1.37 & 1.36 & 1.38 & 1.55 & 1.42 & 0.098 & 0.70 & 0.46 & 0.49 \\
\hline
\end{tabular}


Table 1. Cont.

\begin{tabular}{|c|c|c|c|c|c|c|c|c|c|c|}
\hline \multirow{2}{*}{$\begin{array}{c}\text { Temperature }(\mathrm{T}) \\
\text { Diet }\end{array}$} & \multicolumn{3}{|c|}{ Thermoneutral } & \multicolumn{3}{|c|}{ Heat Stress } & \multirow{2}{*}{ s.e.d. ${ }^{2}$} & \multicolumn{3}{|c|}{$p$-Value ${ }^{3}$} \\
\hline & $\mathrm{CON}^{1}$ & BET & BET + AOX & $\mathrm{CON}^{1}$ & BET & BET + AOX & & $\mathrm{T}$ & BET & $\begin{array}{c}\text { Within } \\
\text { BET }\end{array}$ \\
\hline \multicolumn{11}{|l|}{ Day 21-42 } \\
\hline ADG, g/d & 93.3 & 98.9 & 98.0 & 83.3 & 85.2 & 89.3 & 3.09 & $<0.001$ & 0.10 & 0.61 \\
\hline ADFI, g/d & 182 & 184 & 197 & 164 & 171 & 180 & 7.4 & 0.017 & 0.13 & 0.15 \\
\hline $\begin{array}{l}\text { FCR, g/g } \\
\text { Day 0-42 }\end{array}$ & 1.96 & 1.86 & 2.01 & 1.97 & 2.02 & 2.02 & 0.075 & 0.32 & 0.86 & 0.34 \\
\hline $\mathrm{ADG}, \mathrm{g} / \mathrm{d}$ & 69.4 & 72.9 & 73.8 & 63.3 & 64.7 & 68.1 & 1.99 & $<0.001$ & 0.056 & 0.30 \\
\hline ADFI, g/d & 126 & 124 & 132 & 112 & 120 & 123 & 4.8 & 0.033 & 0.21 & 0.24 \\
\hline FCR, g/g & 1.82 & 1.70 & 1.79 & 1.76 & 1.85 & 1.81 & 0.055 & 0.35 & 0.82 & 0.69 \\
\hline Final weight, g & 2953 & 3103 & 3138 & 2697 & 2755 & 2898 & 83.6 & $<0.001$ & 0.052 & 0.30 \\
\hline Breast weight, g & 672 & 753 & 785 & 596 & 640 & 662 & 24.2 & $<0.001$ & 0.002 & 0.24 \\
\hline
\end{tabular}

${ }^{1}$ Control diet (CON) contained $50 \mathrm{IU} / \mathrm{kg}$ VitE and $0.3 \mathrm{mg} / \mathrm{kg}$ Se. ${ }^{2}$ Standard error of the difference for T $\times \mathrm{CON}$ vs pooled BET. ${ }^{3}$ T-TN vs HS; BET-CON vs pooled BET treatments; Within BET-BET vs BET + AOX.

\subsection{Physiological Responses}

Heat stress increased the rectal temperature $(p<0.001)$ with the response being the greatest $(p<0.001)$ during the afternoon when the ambient temperature was highest (Figure $1 \mathrm{~b})$ and no effects under TN (Figure 1a). Dietary BET tended to reduce rectal temperature in response to dietary BET, particularly towards the end of the experiment, as indicated by the DAY $\times$ BET $(p=0.063)$ interaction. The response appeared to be greater for those chickens receiving dietary BET alone, as indicated by $\mathrm{DAY} \times \mathrm{BET} \times$ within BET interaction $(p=0.004)$ interactions (Figure $1 \mathrm{c}, \mathrm{d})$.
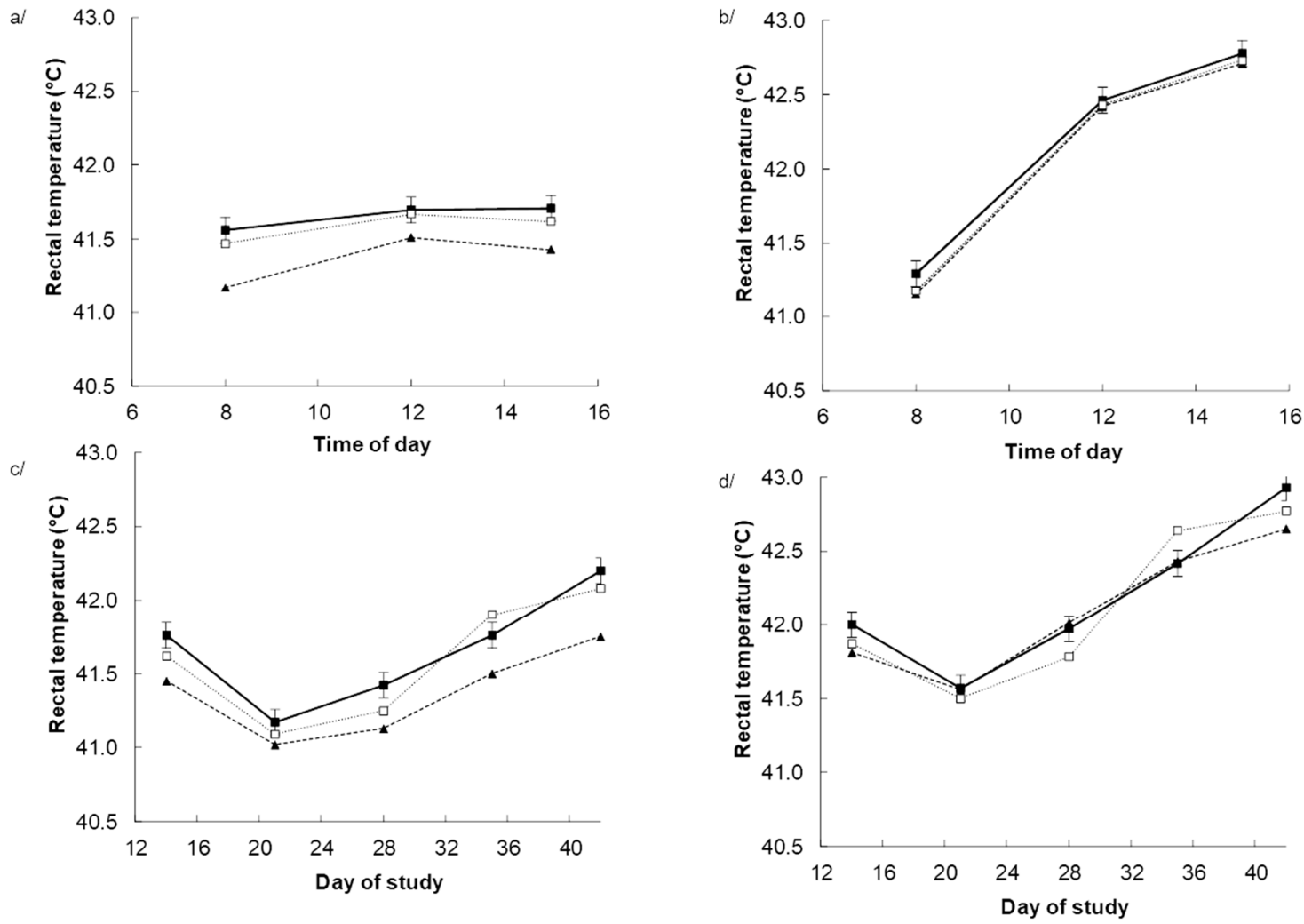

Figure 1. Rectal temperature in chickens fed either a control diet (CON, filled square), the control diet plus betaine (BET, filled triangle) or the control diet plus both BET supplemental antioxidants $(\mathrm{BET}+\mathrm{AOX}$, open square) under either thermoneutral $(\mathbf{a}, \mathbf{c})$ or cyclic heat stress $(\mathbf{b}, \mathbf{d})$. 
Panels ( $\mathbf{a}, \mathbf{b})$ indicate the effect of time of day (TM) pooled across days of the experiment with the standard error of the difference for the interaction between TM, BET, and within BET displayed on the data from the chicken receiving the control diet. Panels $(\mathbf{c}, \mathbf{d})$ indicate the effect of day of experiment pooled across time of day with the standard error of the difference for the interaction between day of experiment (DAY), BET, and AOX displayed on the data from the chicken receiving the control diet. There were main effects $(p<0.10)$ of temperature (TEMP) $(p<0.001)$, DAY $(p<0.001)$ and TM $(p<0.001)$, BET $(p=0.059)$, and TEMP $\times$ Day $(p<0.001)$. TEMP $\times$ TM $(p<0.001)$, DAY $\times$ TM $(p=0.004)$, DAYS $\times$ BET $(p=0.063)$ TEMP $\times$ DAY $\times$ TM $(p<0.001)$ and $($ DAY $\times$ within BET $)$ interactive effects.

There were no other main or interactive effects $(p<0.10)$.

The respiration rate was increased with HS (62.4 vs 141 breaths/min., $p<0.001)$ and it was reduced with BET (118 vs 99 breath/min., $p<0.001$ ) (Figure 2). However, there was a significant interaction $(p<0.001)$ between HS and BET, such that dietary BET reduced respiration rate during HS (171 vs 126 breath/min.), but not under thermoneutral conditions (62.4 vs 62.0 breath/min.) (Figure 2). There were no within BET main or interactive effects indicating that there were no effects of additional AOX over that of BET alone.

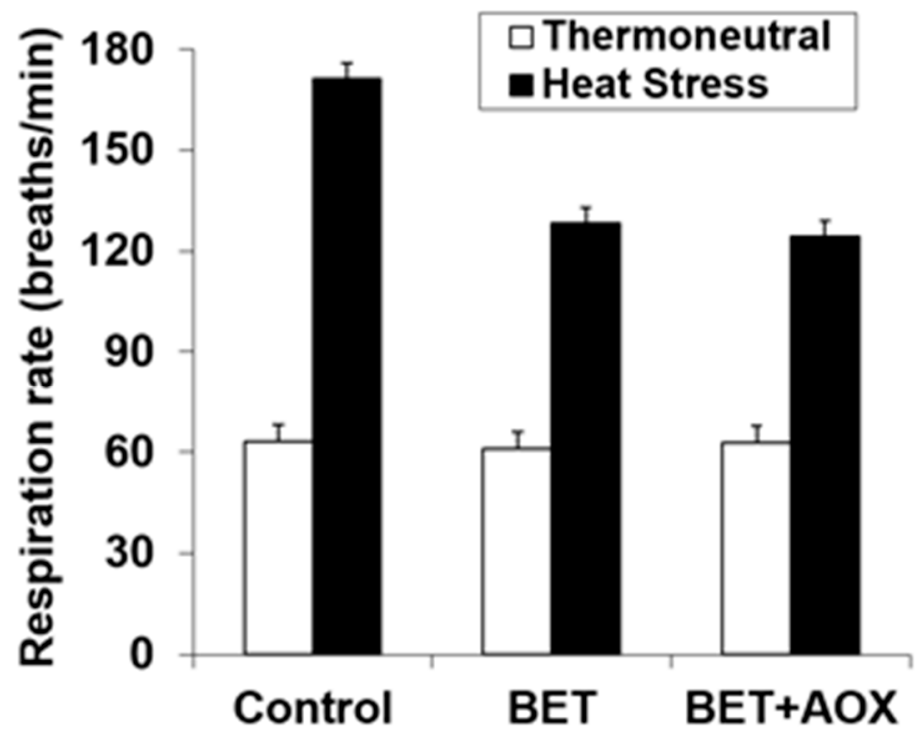

Figure 2. Effect of heat stress and dietary betaine (BET) or BET + AOX (antioxidants) on respiration rate. Since there were no main or interactive effects $(p>0.10)$ of day of study the data are pooled across days 35 and 41 with the standard error of the difference for the interaction between temperature, BET and within BET displayed. There were main effects of temperature (TEMP) $(p<0.001)$ and BET $(p<0.001)$ and a TEMP $\times$ BET $(p<0.001)$ interaction. There were no other main or interactive effects $(p<0.10)$.

Blood $\mathrm{pH}$ increased during HS (7.31 vs 7.39, $p=0.021)$, but it was unchanged by BET (Table 2). Blood partial pressure of $\mathrm{CO}_{2}$ was decreased during $\mathrm{HS}$ (53.4 vs $41.5 \mathrm{~Pa}, p=0.002$ ) and unchanged by BET, whereas there was no effect of HS or BET on the partial pressure of $\mathrm{O}_{2}$. Blood $\mathrm{O}_{2}$ saturation was increased during HS (54.9 vs $64.4 \%, p=0.029$ ), but it was unchanged by BET (Table 2). There was no effect of $\mathrm{HS}$ on total $\mathrm{CO}_{2}$, but there were trends towards an effect of BET $(p=0.067)$ and a within BET effect ( $p=0.058)$, which showed that the combination of BET and AOX increased the total $\mathrm{CO}_{2}$ as compared to both control and BET (26.6 vs 27.4 and $30.3 \mathrm{mM}$ for CON, BET, and BET + AOX, respectively). Blood $\mathrm{HCO}_{3}$ was decreased during $\mathrm{HS}$ (28.1 vs $\left.25.8 \mathrm{mM}, p=0.024\right)$, but it was unchanged by BET. However, there was a within BET effect $(p=0.050)$, such that the combination of BET and AOX increased blood $\mathrm{HCO}_{3}$ when compared to both control and BET (26.0 vs 26.2 and $28.6 \mathrm{mM}$ ). The anion gap tended to be decreased by HS (17.0 vs $15.0 \mathrm{mM}, p=0.089)$ and it was decreased by BET (17.8 vs $15.1 \mathrm{mM}, p=0.039$ ) (Table 2). There was no effect of HS on base excess, whereas BET increased the base excess $(-0.74$ vs $1.09 \mathrm{mM}, p=0.047)$. 
Table 2. Effect of dietary betaine (BET) and antioxidants (AOX) on acid base balance and blood gas during thermoneutral (TN) and heat stress (HS) conditions.

\begin{tabular}{|c|c|c|c|c|c|c|c|c|c|c|}
\hline \multirow{2}{*}{$\begin{array}{c}\text { Temperature }(\mathrm{T}) \\
\text { Diet }\end{array}$} & \multicolumn{3}{|c|}{ Thermoneutral } & \multicolumn{3}{|c|}{ Heat Stress } & \multirow{2}{*}{ s.e.d. ${ }^{2}$} & \multicolumn{3}{|c|}{$p$-Value ${ }^{3}$} \\
\hline & $\mathrm{CON}^{1}$ & BET & BET + AOX & $\mathrm{CON}^{1}$ & BET & BET + AOX & & $\mathrm{T}$ & BET & $\begin{array}{c}\text { Within } \\
\text { BET }\end{array}$ \\
\hline $\mathrm{pH}$ & 7.31 & 7.31 & 7.32 & 7.41 & 7.37 & 7.38 & 0.037 & 0.021 & 0.64 & 0.84 \\
\hline $\mathrm{pCO}_{2}, \mathrm{~mm} \mathrm{Hg}$ & 54.1 & 51.9 & 54.1 & 40.5 & 42.7 & 41.4 & 4.13 & 0.002 & 0.96 & 0.92 \\
\hline Total $\mathrm{CO}_{2}, \mathrm{mM}$ & 27.1 & 27.7 & 32.1 & 26.0 & 27.2 & 28.4 & 1.39 & 0.14 & 0.067 & 0.058 \\
\hline $\mathrm{pO}_{2}, \mathrm{~mm} \mathrm{Hg}$ & 31.3 & 34.0 & 29.6 & 35.1 & 31.9 & 33.9 & 1.61 & 0.15 & 0.54 & 0.47 \\
\hline $\mathrm{O}_{2}$ saturation, $\%$ & 49.2 & 58.8 & 56.8 & 62.0 & 64.0 & 67.1 & 4.88 & 0.029 & 0.17 & 0.91 \\
\hline $\mathrm{HCO}_{3}, \mathrm{mM}$ & 27.3 & 26.5 & 30.4 & 24.7 & 25.9 & 26.8 & 1.14 & 0.024 & 0.17 & 0.050 \\
\hline Anion gap, mM & 19.3 & 16.0 & 15.8 & 16.3 & 15.5 & 13.3 & 1.36 & 0.089 & 0.039 & 0.37 \\
\hline Base excess, mM & -1.38 & -0.23 & 1.90 & -0.10 & 0.93 & 1.78 & 0.994 & 0.36 & 0.047 & 0.15 \\
\hline
\end{tabular}

${ }^{1}$ Control diet (CON) contained $50 \mathrm{IU} / \mathrm{kg}$ VitE and $0.3 \mathrm{mg} / \mathrm{kg}$ Se. ${ }^{2}$ Standard error of the difference for $\mathrm{T} \times \mathrm{CON}$ vs pooled BET. ${ }^{3} \mathrm{~T}$-TN vs HS; BET—CON vs pooled BET treatments; Within BET-BET vs BET + AOX.

Blood haematocrit (21.8 vs $18.3 \%, p=0.003)$ and haemoglobin $(7.25$ vs $6.47, p=0.006)$ decreased during HS, but they were unchanged by BET (Table 3). Blood potassium tended to be decreased by HS (5.99 vs $5.62 \mathrm{mM}, p=0.071$ ) and decreased by BET (6.05 vs $5.68 \mathrm{mM}, p=0.092$ ), whereas there was no effect of either HS or BET on sodium. Blood chloride was increased during HS (111 vs $114 \mathrm{mM}$, $p=0.014)$, but it was unchanged by BET. Blood calcium was decreased during HS (1.47 vs $1.40 \mathrm{mM}$, $p=0.034)$, but it was unchanged by BET. Plasma lactate was decreased during HS (7.43 vs $4.81 \mathrm{mM}$, $p<0.001)$ and was decreased $(p=0.010)$ by BET. However, there was also a strong within BET effect $(p=0.012)$, such that the combination of BET and AOX decreased blood lactate to an even greater extent than BET alone (7.35 vs 6.53 and $4.48 \mathrm{mM}$ for CON, BET, and BET + AOX, respectively). There was no effect of either HS or BET on blood glucose concentrations. Plasma $\mathrm{T}_{3}$ was decreased by HS $(p=0.008)$, while there was no main effect of BET. However, there was a significant interaction between temperature regime and BET $(p=0.018)$, such that plasma $\mathrm{T}_{3}$ was increased by BET under TN conditions (4.76 vs $6.28 \mathrm{pg} / \mathrm{mL}$ ) and decreased under HS conditions (5.16 vs $3.60 \mathrm{pg} / \mathrm{mL}$ ). Plasma $\mathrm{T}_{4}$ concentrations were decreased during HS (4.57vs $3.23 \mathrm{pg} / \mathrm{mL}, p=0.049)$, but it was unchanged by BET.

Table 3. Effect of dietary betaine (BET) and antioxidants (AOX) on haematology, electrolytes, metabolites and plasma thyroid hormones during thermoneutral (TN) and heat stress (HS) conditions.

\begin{tabular}{|c|c|c|c|c|c|c|c|c|c|c|}
\hline \multirow{2}{*}{$\begin{array}{c}\text { Temperature }(\mathrm{T}) \\
\text { Diet }\end{array}$} & \multicolumn{3}{|c|}{ Thermoneutral } & \multicolumn{3}{|c|}{ Heat Stress } & \multirow{2}{*}{ s.e.d. ${ }^{2}$} & \multicolumn{3}{|c|}{$p$-Value ${ }^{3}$} \\
\hline & $\mathrm{CON}^{1}$ & BET & BET + AOX & $\mathrm{CON}^{1}$ & BET & BET + AOX & & $\mathbf{T}$ & BET & $\begin{array}{c}\text { Within } \\
\text { BET }\end{array}$ \\
\hline Haematocrit, \% & 21.5 & 21.8 & 22.0 & 18.8 & 18.0 & 19.8 & 1.04 & 0.003 & 0.78 & 0.35 \\
\hline $\mathrm{Hgb}^{4}, \mathrm{~g} / \mathrm{dL}$ & 6.93 & 7.38 & 7.45 & 6.38 & 6.20 & 6.83 & 0.312 & 0.006 & 0.26 & 0.28 \\
\hline Potassium, mM & 6.38 & 5.80 & 5.80 & 5.73 & 5.83 & 5.30 & 0.239 & 0.071 & 0.092 & 0.29 \\
\hline Sodium, mM & 150 & 149 & 150 & 149 & 150 & 149 & 1.3 & 0.82 & 0.96 & 0.93 \\
\hline Chloride, $\mathrm{mM}$ & 112 & 112 & 110 & 114 & 115 & 114 & 1.3 & 0.014 & 0.82 & 0.26 \\
\hline Calcium, mM & 1.48 & 1.46 & 1.49 & 1.36 & 1.43 & 1.42 & 0.037 & 0.034 & 0.42 & 0.82 \\
\hline Lactate, $\mathrm{mM}$ & 9.17 & 7.89 & 5.24 & 5.53 & 5.17 & 3.73 & 0.74 & $<0.001$ & 0.010 & 0.012 \\
\hline Glucose, mM & 15.6 & 14.5 & 14.8 & 15.2 & 15.7 & 15.5 & 0.61 & 0.30 & 0.56 & 0.92 \\
\hline $\mathrm{T}_{3}^{4,5}, p \mathrm{~g} / \mathrm{mL}$ & 4.76 & 6.47 & 6.08 & 5.16 & 3.76 & 3.43 & 0.977 & 0.008 & 0.97 & 0.61 \\
\hline $\mathrm{T}_{4}{ }^{4}, p \mathrm{~g} / \mathrm{mL}$ & 4.57 & 5.54 & 5.74 & 3.23 & 3.16 & 4.49 & 1.366 & 0.049 & 0.33 & 0.78 \\
\hline
\end{tabular}

${ }^{1}$ Control diet (CON) contained $50 \mathrm{IU} / \mathrm{kg}$ VitE and $0.3 \mathrm{mg} / \mathrm{kg}$ Se. ${ }^{2}$ Standard error of the difference for T $\times \mathrm{CON} v s$ pooled BET. ${ }^{3} \mathrm{~T}$-TN vs HS; BET-CON vs pooled BET treatments; Within BET-BET vs BET + AOX. ${ }^{4}$ Haemoglobin $(\mathrm{Hgb})$; triiodothyronine $\left(\mathrm{T}_{3}\right)$; Thyroxine $\left(\mathrm{T}_{4}\right) .{ }^{5} \mathrm{~T} \times \mathrm{BET}$ interaction $(p=0.018)$.

There were no main or interactive effects of temperature regime on meat colour or $\mathrm{pH}$ the data were pooled for presentation (Table 4). Breast muscle L* increased between 24 and $96 \mathrm{~h}$ post slaughter (54.6 vs 55.2, $p=0.011$ ), although there was an interaction between time and BET ( $p=0.067)$, such that the $\mathrm{L}^{*}$ value increased over time in the breast of those chickens that were fed BET (54.7 vs 55.7), but not in those consuming the CON diet (54.3 vs 54.2) (Table 4). There were no effects of diet or time on $\mathrm{a}^{*}$, 
while $b^{*}$ tended to increase between 24 and $96 \mathrm{~h}$ post slaughter $(1.56$ vs $1.81, p=0.062)$. There was the expected decline $(p<0.001)$ in muscle $\mathrm{pH}$ over the first $24 \mathrm{~h}$ post slaughter. However, there were indications of a within BET $(p=0.094)$ and time $\times$ within BET $(p=0.10)$ effects, such that the initial $\mathrm{pH}$ was higher in breast muscle from those chickens that were supplemented with both BET and AOX (Table 4).

Table 4. Effect of dietary betaine (BET) and antioxidants (AOX) and time on meat colour and pH during thermoneutral (TN) and heat stress (HS) conditions. Since there were no main or interactive effects of HS the data have been pooled across temperature regimes.

\begin{tabular}{|c|c|c|c|c|c|c|c|c|c|c|}
\hline \multirow[b]{2}{*}{ Time/Diet } & \multirow[b]{2}{*}{ Hours } & \multicolumn{3}{|c|}{ Diet } & \multirow{2}{*}{ s.e.d. ${ }^{2}$} & \multicolumn{5}{|c|}{$p$-Value ${ }^{3}$} \\
\hline & & $\mathrm{CON}^{1}$ & BET & BET + AOX & & Time & BET & $\begin{array}{c}\text { Within } \\
\text { BET }\end{array}$ & $\begin{array}{c}\text { Timex } \\
\text { BET }\end{array}$ & $\begin{array}{c}\text { Time } \times \\
\text { within BET }\end{array}$ \\
\hline \multirow[t]{2}{*}{$\mathrm{L}^{*}$} & 24 & 54.3 & 55.1 & 54.3 & 0.967 & 0.011 & 0.31 & 0.52 & 0.061 & 0.82 \\
\hline & 96 & 54.2 & 56.0 & 55.4 & & & & & & \\
\hline \multirow[t]{2}{*}{$a^{*}$} & 24 & 2.20 & 2.50 & 2.30 & 0.283 & 0.91 & 0.68 & 0.57 & 0.26 & 0.82 \\
\hline & 96 & 2.22 & 2.31 & 2.40 & & & & & & \\
\hline \multirow[t]{2}{*}{$b^{*}$} & 24 & 1.43 & 1.59 & 1.65 & 0.268 & 0.062 & 0.97 & 0.49 & 0.77 & 0.82 \\
\hline & 96 & 1.74 & 1.82 & 1.88 & & & & & & \\
\hline \multirow[t]{3}{*}{$\mathrm{pH}$} & 0.25 & 6.68 & 6.68 & 6.78 & 0.053 & $<0.001$ & 0.27 & 0.094 & 0.67 & 0.10 \\
\hline & 1 & 6.48 & 6.49 & 6.58 & & & & & & \\
\hline & 24 & 5.92 & 5.93 & 5.93 & & & & & & \\
\hline
\end{tabular}

\footnotetext{
${ }^{1}$ Control diet (CON) contained $50 \mathrm{IU} / \mathrm{kg}$ VitE and $0.3 \mathrm{mg} / \mathrm{kg} \mathrm{Se} .{ }^{2}$ Standard error of the difference for Time $\times$ CON vs pooled BET. ${ }^{3}$ Time -24 vs 96 or 0.25 vs 1 vs $24 \mathrm{~h}$; BET_CON vs pooled BET treatments; Within BET—BET vs BET + AOX.
}

Cooking loss was decreased in the breast meat from chickens that were exposed to HS (27.3 vs $24.9 \%, p=0.007)$, while there was no main effect of BET. However, there was an indication of an interaction between temperature regime and BET, such that this response was most pronounced in the breast from chickens fed the CON diet (27.5 vs $23.0 \%$ ) rather than those consuming BET (27.2 vs $25.9 \%$ ) (Table 5). While there was no main effect of HS on drip loss there were main $(p=0.007)$ and interactive ( $p=0.052)$ effects of BET such that HS increased drip loss in meat from chickens consuming the CON diet (2.11 vs 3.43\%), but not in those consuming BET (1.76 vs $1.69 \%)$. The total water content tended to be lower after HS (75.7 vs $75.0 \%, p=0.079)$ but was not significantly altered by BET. There were no main or interactive effects of HS or BET on shear force, although there were indications of a $\mathrm{HS} \times \operatorname{BET}(p=0.10)$ and HS $\times$ within BET $(p=0.087)$ interactions that may be attributed to the meat form the chickens consuming the CON diet and housed under TN conditions having the lowest shear force. The MFI was decreased by HS (84.6 vs 67.5) but unchanged by BET. However, there was a highly significant BET effect $(p=0.003)$, which, when coupled with the HS $\times$ BET interaction $(p=0.031)$, clearly showed that the combination of BET and AOX, but not BET alone, protected against the negative effects of HS on MFI (Table 5). There were no effects of HS or BET on TBARS at $0.5 \mathrm{~h}$ post slaughter. However, there were many main and interactive effects at $24 \mathrm{~h}$ post-slaughter. Heat stress increased TBARS post slaughter (3.60 vs 5.65, $p<0.001)$, whereas TBARS were decreased by BET $(5.72$ vs 4.08, $p<0.001)$. However, there was a within BET effect $(p=0.029)$ and HS $\times$ BET $(p=0.008)$ and Hs $\times$ within BET $(p=0.10)$ interactions, such that supplemental AOX provided additional antioxidative effects above BET alone under TN conditions, but to a lesser extent under HS conditions. 
Table 5. Effect of dietary betaine (BET) and antioxidants (AOX) on chicken breast objective eating quality measures during thermonneutral (TN) and heat stress (HS) conditions.

\begin{tabular}{|c|c|c|c|c|c|c|c|c|c|c|}
\hline \multirow{2}{*}{$\begin{array}{c}\text { Temperature (T) } \\
\text { Diet }\end{array}$} & \multicolumn{3}{|c|}{ Thermoneutral } & \multicolumn{3}{|c|}{ Heat Stress } & \multirow{2}{*}{ s.e.d. ${ }^{2}$} & \multicolumn{3}{|c|}{$p$-Value ${ }^{3}$} \\
\hline & $\mathrm{CON}^{1}$ & BET & BET + AOX & $\mathrm{CON}^{1}$ & BET & BET + AOX & & $\mathrm{T}$ & BET & $\begin{array}{c}\text { Within } \\
\text { BET }\end{array}$ \\
\hline Cooking loss ${ }^{4}, \%$ & 27.5 & 27.4 & 26.9 & 23.0 & 25.8 & 26.0 & 1.27 & 0.007 & 0.21 & 0.84 \\
\hline Drip loss $5, \%$ & 2.11 & 1.74 & 1.78 & 3.43 & 1.15 & 2.22 & 0.51 & 0.33 & 0.007 & 0.20 \\
\hline Water content, $\%$ & 74.8 & 76.5 & 75.9 & 74.6 & 75.2 & 75.3 & 0.79 & 0.079 & 0.13 & 0.56 \\
\hline Shear force $^{6}, \mathrm{~N}$ & 18.4 & 20.4 & 23.9 & 23.0 & 22.8 & 21.3 & 1.95 & 0.30 & 0.24 & 0.34 \\
\hline Breast yield, \% & 22.8 & 24.4 & 24.9 & 22.7 & 22.9 & 23.6 & 0.92 & 0.057 & 0.066 & 0.37 \\
\hline MFI $^{7}$ & 86.3 & 79.7 & 87.7 & 58.1 & 62.8 & 81.6 & 6.23 & $<0.001$ & 0.14 & 0.003 \\
\hline $0.5 \mathrm{~h} \mathrm{TBARS}^{8}$ & 0.21 & 0.20 & 0.17 & 0.21 & 0.21 & 0.17 & 0.040 & 0.88 & 0.37 & 0.20 \\
\hline 24 h TBARS 8,9 & 5.32 & 3.48 & 2.00 & 6.12 & 5.51 & 5.32 & 0.545 & $<0.001$ & $<0.001$ & 0.029 \\
\hline
\end{tabular}

${ }^{1}$ Control diet (CON) contained $50 \mathrm{IU} / \mathrm{kg}$ Vit E and $0.3 \mathrm{mg} / \mathrm{kg}$ Se. ${ }^{2}$ Standard error of the difference for $\mathrm{T} \times \mathrm{CON}$ us pooled BET. ${ }^{3} \mathrm{~T}-\mathrm{TN}$ vs HS; BET-CON vs pooled BET treatments; Within BET-BET vs BET + AOX. ${ }^{4} \mathrm{~T} \times$ BET interaction $(p=0.075) .{ }^{5} \mathrm{~T} \times$ BET interaction $(p=0.052) .{ }^{6} \mathrm{~T} \times$ BET $(p=0.10)$ and T $\times$ within BET $(p=0.087)$ interactions. ${ }^{7}$ Myofibrillar fragmentation index (MFI); T $\times$ BET interaction $(p=0.031) .{ }^{8}$ Thiobarbituric acid reactive substances (TBARS) in $\mathrm{mg} / \mathrm{kg}$ of malondialdehyde $(\mathrm{MDA}){ }^{9} \mathrm{~T} \times$ BET $(p=0.008)$ and $\mathrm{T} \times$ within BET $(p=0.10)$ interactions.

Plasma BET concentrations were decreased by HS (123 vs $112 \mu \mathrm{mol} / \mathrm{L}, p=0.043)$ and increased by BET (94.0 vs $130 \mu \mathrm{mol} / \mathrm{L}, p<0.001)$ (Table 6). However, there was a HS x BET interaction $(p=0.002)$, such that HS increased plasma betaine concentrations in chickens consuming the CON diet $(85.0 \mathrm{vs}$ $102 \mu \mathrm{mol} / \mathrm{L})$, whereas it was decreased in those consuming BET (143 vs $117 \mu \mathrm{mol} / \mathrm{L})$. There was no main effect of HS on muscle betaine concentrations, whereas it was increased by dietary BET (373 vs $456 \mu \mathrm{mol} / \mathrm{g}, p=0.009$ ) (Table 6). However, there was a HS $\times$ within BET interaction $(p=0.050)$, such that HS decreased muscle betaine concentrations in chickens that were supplemented with BET alone $(635$ vs $518 \mu \mathrm{mol} / \mathrm{g}$ ), whereas it was increased in those consuming AOX as well as BET (413 vs $567 \mu \mathrm{mol} / \mathrm{g})$. Liver betaine concentrations were decreased by HS (260 vs $165 \mu \mathrm{mol} / \mathrm{g}, p<0.001)$ and decreased by BET (306 vs $166 \mu \mathrm{mol} / \mathrm{g}, p<0.001$ ) (Table 6). However, there was a HS $\times$ BET interaction, such that HS decreased liver betaine concentrations to a greater extent in chickens on the CON diet (403 vs $189 \mu \mathrm{mol} / \mathrm{g}$ ) whereas it was decreased in those consuming BET (208 vs $144 \mu \mathrm{mol} / \mathrm{g}$ ). Indeed, chickens consuming the CON diet and housed under TN conditions had the highest liver betaine concentrations. Although statistical comparisons were made, there appeared to be a $>1000$ fold difference between the plasma and tissue betaine concentrations, suggesting an accumulation against a strong concentration gradient.

Table 6. Effect of dietary betaine (BET) and antioxidants (AOX) on plasma and tissue betaine concentrations during thermonneutral (TN) and heat stress (HS) conditions.

\begin{tabular}{|c|c|c|c|c|c|c|c|c|c|c|}
\hline \multirow{2}{*}{$\begin{array}{c}\text { Temperature (T) } \\
\text { Diet }\end{array}$} & \multicolumn{3}{|c|}{ Thermoneutral } & \multicolumn{3}{|c|}{ Heat Stress } & \multirow{2}{*}{ s.e.d. ${ }^{2}$} & \multicolumn{3}{|c|}{$p$-Value ${ }^{3}$} \\
\hline & $\mathrm{CON}^{1}$ & BET & BET + AOX & $\mathrm{CON}^{1}$ & BET & BET + AOX & & $\mathrm{T}$ & BET & $\begin{array}{c}\text { Within } \\
\text { BET }\end{array}$ \\
\hline Plasma ${ }^{4}, \mu \mathrm{mol} / \mathrm{L}$ & 85.0 & 140 & 145 & 102 & 109 & 125 & 10.50 & 0.043 & $<0.001$ & 0.14 \\
\hline Muscle $^{5}, \mu \mathrm{mol} / \mathrm{g}$ & 321 & 635 & 413 & 425 & 518 & 567 & 9.38 & 0.43 & 0.009 & 0.16 \\
\hline Liver ${ }^{6}, \mu \mathrm{mol} / \mathrm{g}$ & 403 & 191 & 187 & 208 & 143 & 145 & 45.1 & $<0.001$ & $<0.001$ & 0.98 \\
\hline
\end{tabular}

${ }^{1}$ Control diet $(\mathrm{CON})$ contained $50 \mathrm{IU} / \mathrm{kg}$ Vit $\mathrm{E}$ and $0.3 \mathrm{mg} / \mathrm{kg}$ Se. ${ }^{2}$ Standard error of the difference for $\mathrm{T} \times \mathrm{CON} v \mathrm{~s}$ pooled BET. ${ }^{3} \mathrm{~T}-\mathrm{TN}$ vs HS; BET-CON vs pooled BET treatments; Within BET-BET vs BET + AOX. ${ }^{4} \mathrm{~T} \times \mathrm{BET}$ interaction $(p=0.002) .{ }^{5} \mathrm{~T} \times$ within BET interaction $(p=0.050) .{ }^{6} \mathrm{~T} \times$ BET interaction $(p=0.002)$.

\section{Discussion}

The principal findings of this study were that the supplementation of BET alone or in combination with AOX ameliorated symptoms of HS in broilers, as evidenced by reduced respiration rate and rectal temperature. This corresponded to improvements in productive performance, with BET improving the final body and breast weights, irrespective of HS or additional antioxidant supplementation. Betaine 
supplementation resulted in accumulation within the breast muscle and this corresponded to improved meat quality, namely improved drip loss and lipid stability post-mortem. The temperature profile that was used in this study markedly increased the respiration rate and blood $\mathrm{pH}$, indicating that the broilers were experiencing both HS and respiratory alkalosis. In agreement with other studies, this resulted in an adaptive endocrine state, reducing thyroid hormone concentrations and growth performance [13,15,35-37]. Heat stress reduced meat quality, tending to reduce moisture content, increase lipid oxidation, and reduce MFI, a marker of post-mortem myofibrillar breakdown and proteolytic activity. In general, the positive effects of betaine on HS amelioration were not augmented with antioxidant co-supplementation. However, when BET was combined with AOX, there were positive effects on meat quality, reducing postmortem myofibrillar degradation and lipid peroxidation.

Betaine is accumulated in plant and animal tissue when under osmotic stress, and it has previously been reported to accumulate in the hepatic tissue of chicks [38]. Surprisingly, in this study, hepatic BET concentrations were lower with BET and BET + AOX supplementation. The opposite pattern was observed in skeletal muscle, which had higher overall concentrations than the liver. Betaine distribution changed during HS, with concentrations falling in the liver and increasing by $\sim 30 \%$ in HS CON chickens. The BET and BET + AOX supplemented chickens further increased their BET concentrations by another $30 \%$, under TN or HS conditions. As an osmolyte, BET reduces the osmotic gradients, and therefore the activity of cellular ATPases that is required to maintain them [39]. The energy saving from reduced ATPase activity could be substantial, and approximated to be as much as $8 \%$ [40]. Although no interactions were observed with circulating thyroid hormones, the reduction of basal metabolic rate has parallels to adaptive endocrine regulation of by thyroid hormones during HS. Triodothyroxine and $\mathrm{T}_{4}$ were lower in this study and others [41], and, amongst their biological roles, thyroid hormones serve to set basal metabolic rate though regulating the rate of futile cycling of cellular ATPases. Perhaps part of the reason for the accumulation of betaine in skeletal muscle during HS is thermoregulatory, and a reflection on the physical size of the organ and its contribution to basal metabolic rate. Alternatively, it may reflect accumulation as a protective chaperone.

It has been reported elsewhere that the elimination of betaine is primarily by metabolism and not excretion [42]. Furthermore, the liver is a major site of BET utilization through methyl donor reactions to the methionine cycle via betaine homocysteine methyltransferase (BHMT) and other metabolic pathways. It requires further investigation; however, it is possible that the reductions in hepatic betaine that were observed with supplementation may reflect an increase in utilization. Outside of the DNA methylation reactions, the fates of betaine could be increased remethylation of homocysteine to methionine as part of the methionine cycle. Methionine is an essential amino acid, which is utilized in protein synthesis, as a precursor to cysteine, taurine, and glutathione. If so, this apparent increase in hepatic betaine utilization may explain some of the protective effect of betaine during HS and enhanced growth performance seen in this study and elsewhere [43-45]. It has been indicated that the antioxidant properties of betaine provide protection by relieving oxidative pressure and increasing productivity, and the enhancement of meat quality in poultry under stress conditions [46]. During HS, betaine adjusts osmotic pressure, preserves water in cells [43,47], and reduces energy expenditure used in the sodium-potassium pump, which reduces the production of heat from metabolic pathways [48]. By reducing heat production, deep body temperature and respiration rate will decrease, as the chicken's body does not produce extra heat. Moreover, Se and Vit E are an important part of many metabolic pathways and they enhance immunity, which can improve body temperature management and reduce oxidative damages in cells $[49,50]$. However, the present results showed no positive effects of Se and VitE on growth performance, which is in line with [50,51]. Indeed, the establishment of Se and VitE requirements are difficult, mainly because of their interactions with diverse factors that may affect the necessity of diet supplementation and the physiological status of the broiler chickens [52].

The present results of blood analysis are in line with a study showing that sodium was unchanged and potassium was decreased with HS [53], while a study reported a reduction of both sodium and potassium [54]. Apparently, the time of blood sampling could be a reason for differences of the results. 
During HS, hemodilution occurs as the chicken's body temperature increased due to a reduction of sodium concentration, and some of the tissue potassium exits into the bloodstream apparently due to altered membrane permeability [55]. The results are agreement with studies that showed HS increased blood $\mathrm{pH}[53,56]$ and reduced $\mathrm{HCO}_{3}$ and chloride, $\mathrm{pCO}_{2}$, and haematocrit $[53,57]$. The increased body temperature that occurs during HS causes broiler chickens to reduce their body temperature through different mechanisms, such as increasing respiration rate. Respiration rate is increased to dissipate heat as well as being a response to the increase in blood $\mathrm{pH}$, owing to respiratory alkalosis. Subsequently, more calcium is needed to exert an acidic action to balance blood $\mathrm{pH}$, resulting in a reduction of $\mathrm{HCO}_{3}$. An increased $\mathrm{HCO}_{3}$ level in BET + AOX could be related to supplementation of Se that increases calcium release from the sarcoplasmic reticulum [58], which is responsible for storing calcium ions. Respiratory alkalosis causes a primary deficit of $\mathrm{CO}_{2}$, and hence causes the ratio of bicarbonate to $\mathrm{pCO}_{2}$ to increase, resulting in increased $\mathrm{pH}$. Subsequently, the kidneys attempt to normalize blood $\mathrm{pH}$ by increasing the excretion of $\mathrm{HCO}_{3}$ by reclaiming $\mathrm{H}^{+}$and by decreasing $\mathrm{HCO}_{3}$. Total $\mathrm{CO}_{2}$ was higher for BET + AOX that could be attributed to Se level, as it was indicated that higher dosages of Se caused pulmonary congestion and haemorrhages in lungs [59], which could reduce the ability of lungs to reduce the $\mathrm{CO}_{2}$ in blood. However, this cannot only be attributed to Se, as the total $\mathrm{CO}_{2}$ also increased for BET. This could be related to heavier chickens, there is a negative relationship between surface area available for exchange in lungs and body size [60]. The decreased haematocrit could be related to increased circulating blood volume [61] due to an increase in plasma volume and a lesser increase in the total red blood cells. In broilers, it was observed that the haematocrit decreased when the environmental temperature is higher than $30{ }^{\circ} \mathrm{C}$ [62]. Therefore, as hemoglobin is a protein in red blood cells that is responsible for delivery of oxygen, haematocrit reduction results in a reduction of hemoglobin [63]. Unexpectedly, lactate in blood was reduced with HS, BET, and BET + AOX, while the duration of recovery time after exposure to HS could be a reason for this reduction [64]. Furthermore, BET and BET + AOX could provide sufficient energy for the body by reducing body temperature to avoid anaerobic pathways, due to lower lactic acid. The thyroid hormones have major function in the control of metabolic rate and thermogenesis in broiler [65]. The results of the present study confirmed with [65-67] showed that $\mathrm{HS}$ reduces both $\mathrm{T}_{3}$ and $\mathrm{T}_{4}$. A reduction in thyroid hormones production during HS is one of the pathways for maintenance of homeostasis [65]. While the $\mathrm{T}_{3}$ results under HS are consistent in most studies and have shown reduction [68-70], the $\mathrm{T}_{4}$ results are inconsistent among studies that showed reduction [71], increase [69], or no alteration [72]. While there is a correlation between ultimate muscle $\mathrm{pH}$ and colour, $\mathrm{pH}$ is not the only factor that impacts meat color [73]. In the present study there were no effects of HS on $\mathrm{pH}$ or colour, which disagrees with studies that argued that both cyclic and consistent HS could reduce initial and ultimate $\mathrm{pH}[74,75]$. However, other studies support the present results, which showed that consistent HS [27] and short term HS have no effects on the initial and ultimate $\mathrm{pH}$ [76]. Furthermore, $\mathrm{pH}$ level reduction over time agrees with [77,78]. These studies could provide the insight that the duration of HS is an important factor that could affect $\mathrm{pH}$ level. From the colour aspect, the results are in line with [74], which indicated that HS has no effect on colour. Lighter breast muscles over time in BET is related to BET functioning as an osmolyte that can improve and regulate cells osmotic balance [79]. The amount of water available in meat is important, as losing water could affect the weight and correspondingly the economic value of the final product. Additionally, it may affect the appearance, the juiciness, and the tenderness of the meat. The results of the present study agree with [80-83], which indicated that HS increases water loss, which is evident in the reduced total water content, resulting in reduced cooking loss and reduced breast yield, whereas BET could improve it. It is likely that HS causes leaky membranes, resulting in loss of water from muscle cells and it would explain the reduced muscle total water content and reduced breast yield. Betaine, as an osmolyte, maintains the osmotic pressure to prevent dehydration and preserves water in cells [84]. The present results are in disagreement with [80,85], which showed that HS increased shear force; however, the results agree with [86], where HS has no impact on shear force. The duration of HS could be a reason for inconsistent results among studies. 
Although no overall differences in WBSF were observed in this study, there was a reduction in the MFI in HS broilers. Texture measurements, such as WBSF, measure the force required to shear through the myofibrils and connective tissue in a standard block of meat and they are a product of both the skeletal muscle fibres and connective tissue. Alternatively, MFI is only a measure of the myofibrillar filament fragmentation. The meat tenderization process is initiated by calpain mediated proteolysis of the skeletal muscle fibre, forming smaller fragments and an increase in the MFI [87]. The results of this study agree with $[74,80]$ that HS reduces MFI. The mechanism is that, because HS generates high amounts of reactive oxygen species, this either (i) leads to the oxidation of myofibrillar proteins that can cause protein cross-linking and toughness or (ii) leads to the direct oxidation of calpain, preventing proteolysis from occurring, or a combination of both [88]. Elsewhere, HS has been observed to increase Atrogin-1 gene expression, which is associated with muscle wasting, which would likely have consequences for meat tenderisation. Notably, BET + AOX improved MFI under HS, which may indicate that BET, in combination with AOX, provides a number of benefits to both product yield and quality.

Lipid oxidation, a process during which meat lipids oxidize and interact with other meat constituents, causes deterioration in the quality of meat and it causes undesirable effects in nutritive value. The TBARS in biological pathways, which include lipid hydroperoxides, increases in response to oxidative stress. The results are consistent with $[82,89,90]$, whose studies indicated that HS increases the oxidative damages to muscle due to increased TBARS. Heat stress generates a high amount of reactive oxygen species due to the denaturation of proteins and cell death, which results in higher oxidative damages in tissues [82]. Moreover, it has been indicated that additives, such as BET, can improve TBARS concentration and preserve the cellular antioxidant storage under stress conditions [13,82], and there are additional effects of antioxidants $[50,91]$ through removing ROS. In this context, the combination of dietary BET and AOX reduced meat TBARS to a greater extent than BET alone.

\section{Conclusions}

Supplemented BET conferred overall benefits, as well as improved resilience against HS in this small university study. Some additional benefits, such as increased MFI and decreased plasma lactate and muscle TBARS, were provided by supplemental BET + AOX. This study appears to show that supplemented BET is utilized by the liver, potentially to benefit important metabolic pathways, such as the methionine cycle and antioxidant production. However, this requires further investigation. Likewise, accumulation in skeletal muscle may also have a protective effect and contribute to improved growth and meat quality. The additional effects of AOX warrant further investigation, particularly with respect to shelf life and oxidation.

Author Contributions: Conceptualization, M.S., J.J.C., S.W., R.D.W. and F.R.D.; Data curation, M.S. and F.R.D.; Formal analysis, M.S., H.H.L., H.A.R.S. and F.R.D.; Funding acquisition, J.J.C. and F.R.D.; Investigation, M.S. and H.H.L.; Methodology, S.W., H.H.L., H.A.R.S., R.D.W. and F.R.D.; Project administration, M.S., J.J.C. and F.R.D.; Resources, J.J.C. and S.W.; Supervision, J.J.C., S.W. and F.R.D.; Writing—original draft, M.S.; Writing-review \& editing, J.J.C., S.W., H.A.R.S., R.D.W. and F.R.D.

Funding: This research was funded by Melbourne International Research Scholarship (MIRS) and Melbourne International Fee Remission Scholarship (MIFRS).

Acknowledgments: We are grateful to staff members of the animal house for their support during the experiment. We would like also to thank Tri Foods Pty. Ltd. (Bannockburn Victoria, Australia) for providing the chickens' feed.

Conflicts of Interest: The authors declare no conflict of interest.

\section{References}

1. Henry, B.; Charmley, E.; Eckard, R.; Gaughan, J.B.; Hegarty, R. Livestock production in a changing climate: Adaptation and mitigation research in Australia. Crop Pasture Sci. 2012, 63, 191-202. [CrossRef]

2. Renaudeau, D.; Collin, A.; Yahav, S.; De Basilio, V.; Gourdine, J.; Collier, R.J. Adaptation to hot climate and strategies to alleviate heat stress in livestock production. Animal 2012, 6, 707-728. [CrossRef] [PubMed] 
3. Geraert, P.; Padilha, J.; Guillaumin, S. Metabolic and endocrine changes induced by chronic heatexposure in broiler chickens: Growth performance, body composition and energy retention. Br. J. Nutr. 1996, 75, 195-204. [CrossRef] [PubMed]

4. Temim, S.; Chagneau, A.-M.; Peresson, R.; Tesseraud, S. Chronic heat exposure alters protein turnover of three different skeletal muscles in finishing broiler chickens fed 20 or $25 \%$ protein diets. J. Nutr. 2000, 130, 813-819. [CrossRef] [PubMed]

5. Ezzine, S.B.-O.; Everaert, N.; Metayer-Coustard, S.; Rideau, N.; Berri, C.; Joubert, R.; Temim, S.; Collin, A.; Tesseraud, S. Effects of heat exposure on Akt/S6K1 signaling and expression of genes related to protein and energy metabolism in chicken (Gallus gallus) pectoralis major muscle. Comp. Biochem. Physiol. B 2010, 157, 281-287. [CrossRef] [PubMed]

6. Akşit, M.; Yalcin, S.; Özkan, S.; Metin, K.; Özdemir, D. Effects of temperature during rearing and crating on stress parameters and meat quality of broilers. Poult. Sci. 2006, 85, 1867-1874. [PubMed]

7. Love, J.D.; Pearson, A.M. Lipid oxidation in meat and meat products-A review. J. Am. Oil Chem. Soc. 1971, 48, 547-549. [CrossRef]

8. Rajagopal, K.; Oommen, G.T. Myofibril fragmentation index as an immediate postmortem predictor of Buffalo meat tenderness. J. Food Process. Preserv. 2015, 39, 1166-1171. [CrossRef]

9. Huang, C.; Jiao, H.; Song, Z.; Zhao, J.; Wang, X.; Lin, H. Heat stress impairs mitochondria functions and induces oxidative injury in broiler chickens. J. Anim. Sci. 2015, 93, 2144-2153. [CrossRef] [PubMed]

10. DiGiacomo, K.; Leury, B.J.; Dunshea, F.R. Potential nutritional strategies for the amelioration or prevention of high rigor temperature in cattle-A review. Anim. Prod. Sci. 2014, 54, 430-443. [CrossRef]

11. Cottrell, J.J.; Ponnampalam, E.N.; Dunshea, F.R.; Warner, R.D. Effects of infusing nitric oxide donors and inhibitors on plasma metabolites, muscle lactate production and meat quality in lambs fed a high quality roughage-based diet. Meat Sci. 2015, 105, 8-15. [CrossRef] [PubMed]

12. Craig, S.A.S. Betaine in human nutrition. Am. J. Clin. Nutr. 2004, 80, 539-549. [CrossRef] [PubMed]

13. Alirezaei, M.; Gheisari, H.R.; Ranjbar, V.R.; Hajibemani, A. Betaine: A promising antioxidant agent for enhancement of broiler meat quality. Br. Poult. Sci. 2012, 53, 699-707. [CrossRef] [PubMed]

14. Alirezaei, M.; Khoshdel, Z.; Dezfoulian, O.; Rashidipour, M.; Taghadosi, V. Beneficial antioxidant properties of betaine against oxidative stress mediated by levodopa/benserazide in the brain of rats. J. Physiol. Sci. 2015, 65, 243-252. [CrossRef] [PubMed]

15. Shakeri, M.; Cottrell, J.J.; Wilkinson, S.; Ringuet, M.; Furness, J.; Dunshea, F.R. Betaine and Antioxidants Improve Growth Performance, Breast Muscle Development and Ameliorate Thermoregulatory Responses to Cyclic Heat Exposure in Broiler Chickens. Animals 2018, 8, 162. [CrossRef]

16. Tsai, M.T.; Chen, C.Y.; Pan, Y.H.; Wang, S.H.; Mersmann, H.J.; Ding, S.T. Alleviation of carbon-tetrachloride-induced liver injury and fibrosis by betaine supplementation in chickens. Evid. Based Complement. Alternat. Med. 2015, 2015, 725379. [CrossRef]

17. Dunshea, F.R.; Leury, B.J.; Fahri, F.; DiGiacomo, K.; Hung, A.; Chauhan, S.; Clarke, I.J.; Collier, R.; Little, S.; Baumgard, L. Amelioration of thermal stress impacts in dairy cows. Anim. Prod. Sci. 2013, 53, 965-975. [CrossRef]

18. Suster, D.; Leury, B.J.; King, R.H.; Mottram, M.; Dunshea, F.R. Interrelationships between porcine somatotropin (pST), betaine, and energy level on body composition and tissue distribution of finisher boars. Aust. J. Agric. Res. 2004, 55, 983-990. [CrossRef]

19. Sun, H.; Yang, W.R.; Yang, Z.B.; Wang, Y.; Jiang, S.Z.; Zhang, G.G. Effects of betaine supplementation to methionine deficient diet on growth performance and carcass characteristics of broilers. Am. J. Anim. Vet. Sci. 2008, 3, 78-84. [CrossRef]

20. Attia, Y.A.; Hassan, R.A.; Qota, E.M.A. Recovery from adverse effects of heat stress on slow-growing chicks in the tropics 1: Effect of ascorbic acid and different levels of betaine. Trop. Anim. Health Prod. 2009, 41, 807-818. [CrossRef]

21. Oliveira, T.F.B.; Rivera, D.F.R.; Mesquita, F.R.; Braga, H.; Ramos, E.M.; Bertechini, A.G. Effect of different sources and levels of selenium on performance, meat quality, and tissue characteristics of broilers. J. Appl. Poult. Res. 2014, 23, 15-22. [CrossRef]

22. Zhou, X.; Wang, Y. Influence of dietary nano elemental selenium on growth performance, tissue selenium distribution, meat quality, and glutathione peroxidase activity in Guangxi Yellow chicken. Poult. Sci. 2011, 90, 680-686. [CrossRef] [PubMed] 
23. Perić, L.; Milošević, N.; Žikić, D.; Kanački, Z.; Džinić, N.; Nollet, L.; Spring, P. Effect of selenium sources on performance and meat characteristics of broiler chickens. J. Appl. Poult. Res. 2009, 18, 403-409. [CrossRef]

24. Choct, M.; Naylor, A.J.; Reinke, N. Selenium supplementation affects broiler growth performance, meat yield and feather coverage. Br. Poult. Sci. 2004, 45, 677-683. [CrossRef] [PubMed]

25. Gao, J.; Lin, H.; Wang, X.J.; Song, Z.G.; Jiao, H.C. Vitamin E supplementation alleviates the oxidative stress induced by dexamethasone treatment and improves meat quality in broiler chickens. Poult. Sci. 2010, 89, 318-327. [CrossRef] [PubMed]

26. Sahin, K.; Kucuk, O. Effects of vitamin $\mathrm{C}$ and vitamin $\mathrm{E}$ on performance, digestion of nutrients and carcass characteristics of Japanese quails reared under chronic heat stress (34C). J. Anim. Physiol. Anim. Nutr. (Berl.) 2001, 85, 335-341. [CrossRef]

27. Hashizawa, Y.; Kubota, M.; Kadowaki, M.; Fujimura, S. Effect of dietary vitamin E on broiler meat qualities, color, water-holding capacity and shear force value, under heat stress conditions. Anim. Sci. J. 2013, 84, 732-736. [CrossRef] [PubMed]

28. Aviagen Broiler Breeders. Ross Broiler Management Manual; Aviagen: Midlothian, Scotland, UK, 2009; pp. 1-114.

29. NRC. Nutrient Requirements of Poultry; National Academy Press: Washington, DC, USA, 1994.

30. Culler, R.D.; Smith, G.C.; Cross, H.R. Relationship of myofibril fragmentation index to certain chemical, physical and sensory characteristics of bovine longissimus muscle. J. Food Sci. 1978, 43, 1177-1180. [CrossRef]

31. Koohmaraie, M.; Seidemann, S.C.; Schollmeyer, J.E.; Dutson, T.R.; Crouse, J.D. Effect of post-mortem storage on $\mathrm{Ca}++-$ dependent proteases, their inhibitor and myofibril fragmentation. Meat Sci. 1987, 19, 187-196. [CrossRef]

32. Ohkawa, H.; Ohishi, N.; Yagi, K. Assay for lipid peroxides in animal tissues by thiobarbituric acid reaction. Anal. Biochem. 1979, 95, 351-358. [CrossRef]

33. Laryea, M.D.; Steinhagen, F.; Pawliczek, S.; Wendel, U. Simple method for the routine determination of betaine and N, N-dimethylglycine in blood and urine. Clin. Chem. 1998, 44, 1937-1941. [PubMed]

34. Dunshea, F.R.; Ostrowska, E.; Luxford, B.; Smits, R.J.; Campbell, R.G.; DSouza, D.N.; Mullan, B.P. Dietary conjugated linoleic acid can decrease backfat in pigs housed under commercial conditions. Asian-Australas. J. Anim. Sci. 2002, 15, 1011-1017. [CrossRef]

35. He, S.; Zhao, S.; Dai, S.; Liu, D.; Bokhari, S.G. Effects of dietary betaine on growth performance, fat deposition and serum lipids in broilers subjected to chronic heat stress. Anim. Sci. J. 2015, 86, 897-903. [CrossRef] [PubMed]

36. Nofal, M.E.; Magda, A.G.; Mousa, S.M.M.; Doaa, M.M.; Bealsh, A.M.A. Effect of dietary betaine supplementation on productive, physiological and immunological performance and carcass characteristic of growing developed chicks uinder the condition of heat stress. Egypt. Poult. Sci. J. 2015, 35, 237-259.

37. Mello, J.; Boiago, M.; Giampietro-Ganeco, A.; Berton, M.; Vieira, L.; Souza, R.; Ferrari, F.; Borba, H. Periods of heat stress during the growing affects negatively the performance and carcass yield of broilers. Arch. Zootec. 2015, 64, 339-345. [CrossRef]

38. Kettunen, H.; Tiihonen, K.; Peuranen, S.; Saarinen, M.; Remus, J. Dietary betaine accumulates in the liver and intestinal tissue and stabilizes the intestinal epithelial structure in healthy and coccidia-infected broiler chicks. Comp. Biochem. Physiol. A 2001, 130, 759-769. [CrossRef]

39. Moeckel, G.W.; Shadman, R.; Fogel, J.M.; Sadrzadeh, S.M. Organic osmolytes betaine, sorbitol and inositol are potent inhibitors of erythrocyte membrane ATPases. Life Sci. 2002, 71, 2413-2424. [CrossRef]

40. Cronje, P. Heat stress in livestock-The role of the gut in its aetiology and a potential role for betaine in its alleviation. Rec. Adv. Anim. Nutr. Aust. 2005, 15, 107-122.

41. Raghebian, M.; Sadeghi, A.A.; Aminafshar, M. Energy sources and levels influenced on performance parameters, thyroid hormones, and HSP70 gene expression of broiler chickens under heat stress. Trop. Anim. Health Prod. 2016, 48, 1697-1702. [CrossRef] [PubMed]

42. Schwahn, B.C.; Hafner, D.; Hohlfeld, T.; Balkenhol, N.; Laryea, M.D.; Wendel, U. Pharmacokinetics of oral betaine in healthy subjects and patients with homocystinuria. Br. J. Clin. Pharmacol. 2003, 55, 6-13. [CrossRef] [PubMed]

43. Eklund, M.; Bauer, E.; Wamatu, J.; Mosenthin, R. Potential nutritional and physiological functions of betaine in livestock. Nutr. Res. Rev. 2005, 18, 31-48. [CrossRef] [PubMed] 
44. Sayed, M.; Downing, J. The effects of water replacement by oral rehydration fluids with or without betaine supplementation on performance, acid-base balance, and water retention of heat-stressed broiler chickens. Poult. Sci. 2011, 90, 157-167. [CrossRef] [PubMed]

45. Zhang, M.; Zhang, H.; Li, H.; Lai, F.; Li, X.; Tang, Y.; Min, T.; Wu, H. Antioxidant mechanism of betaine without free radical scavenging ability. J. Agric. Food Chem. 2016, 64, 7921-7930. [CrossRef] [PubMed]

46. Akhavan-Salamat, H.; Ghasemi, H.A. Alleviation of chronic heat stress in broilers by dietary supplementation of betaine and turmeric rhizome powder: Dynamics of performance, leukocyte profile, humoral immunity, and antioxidant status. Trop. Anim. Health Prod. 2016, 48, 181-188. [CrossRef] [PubMed]

47. Attia, Y.A.; Hassan, R.A.; Shehatta, M.H.; Abd-El-Hady, S.B. Growth, carcass quality and serum constituents of slow growing chicks as affected by betaine addition to diets containing 2. Different levels of methionine. Int. J. Poult. Sci. 2005, 4, 856-865.

48. Remus, J. Betaine for increased breast meat yield in turkeys. World Poult. 2001, 17, 14-15.

49. Swain, B.K.; Johri, T.S.; Majumdar, S. Effect of supplementation of vitamin E, selenium and their different combinations on the performance and immune response of broilers. Br. Poult. Sci. 2000, 41, 287-292. [CrossRef]

50. Habibian, M.; Ghazi, S.; Moeini, M.M. Effects of dietary selenium and vitamin E on growth performance, meat yield, and selenium content and lipid oxidation of breast meat of broilers reared under heat stress. Biol. Trace Elem. Res. 2016, 169, 142-152. [CrossRef]

51. Zduńczyk, Z.; Gruzauskas, R.; Semaskaite, A.; Juskiewicz, J.; Raceviciute-Stupeliene, A.; Wroblewska, M. Fatty acid profile of breast muscle of broiler chickens fed diets with different levels of selenium and vitamin E. Arch. Geflugelkd. 2011, 75, 264-267.

52. Kuttappan, V.A.; Goodgame, S.D.; Bradley, C.D.; Mauromoustakos, A.; Hargis, B.M.; Waldroup, P.W.; Owens, C.M. Effect of different levels of dietary vitamin E (DL- $\alpha$-tocopherol acetate) on the occurrence of various degrees of white striping on broiler breast fillets. Poult. Sci. 2012, 91, 3230-3235. [CrossRef]

53. Borges, S.A.; Fischer da Silva, A.V.; Majorka, A.; Hooge, D.M.; Cummings, K.R. Physiological responses of broiler chickens to heat stress and dietary electrolyte balance (sodium plus potassium minus chloride, milliequivalents per kilogram). Poult. Sci. 2004, 83, 1551-1558. [CrossRef] [PubMed]

54. Ait-Boulahsen, A.; Garlich, J.D.; Edens, F.W. Potassium chloride improves the thermotolerance of chickens exposed to acute heat stress. Poult. Sci. 1995, 74, 75-87. [CrossRef] [PubMed]

55. Smith, M.O.; Teeter, R.G. Potassium balance of the 5 to 8-week-old broiler exposed to constant heat or cycling high temperature stress and the effects of supplemental potassium chloride on body weight gain and feed efficiency. Poult. Sci. 1987, 66, 487-492. [CrossRef]

56. Teeter, R.G.; Smith, M.O.; Owens, F.N.; Arp, S.C.; Sangiah, S.; Breazile, J.E. Chronic heat stress and respiratory alkalosis: Occurrence and treatment in broiler chicks. Poult. Sci. 1985, 64, 1060-1064. [CrossRef] [PubMed]

57. Altan, Ö.; Altan, A.; Çabuk, M.; Bayraktar, H. Effects of heat stress on some blood parameters in broilers. Turk. J. Vet. Anim. Sci. 2000, 24, 145-148.

58. Bodnár, D.; Ruzsnavszky, O.; Oláh, T.; Dienes, B.; Balatoni, I.; Ungvári, É.; Benkő, I.; Babka, B.; Prokisch, J.; Csernoch, L. Dietary selenium augments sarcoplasmic calcium release and mechanical performance in mice. Nutr. Metab. (Lond.) 2016, 13, 76. [CrossRef] [PubMed]

59. Kumar, D.; Gautam, A.K.; Sinha, M.K. Histopathological alterations of selenium toxicity induced in broiler (Birds). Indian J. Anim. Res. 2018, 52, 599-604.

60. Maina, J.N.; King, A.; Settle, G. An allometric study of pulmonary morphometric parameters in birds, with mammalian comparisons. Philos. Trans. R Soc. Lond. B Biol. Sci. 1989, 326, 1-57. [CrossRef]

61. Zhou, W.T.; Fujita, M.; Yamamoto, S. Effects of ambient temperatures on blood viscosity and plasma protein concentration of broiler chickens (Gallus domesticus). J. Therm. Biol. 1999, 24, 105-112. [CrossRef]

62. Zhou, W.T. Heat-induced the shift of body fluid in broiler chickens. In Proceedings of the 6th Asian Pacific Poultry Congress, Nagoya, Japan, 4-7 June 1998.

63. Billett, H.H. Hemoglobin and hematocrit. In Clinical Methods: The History, Physical, and Laboratory Examinations, 3rd ed.; Butterworths: London, UK, 1990.

64. Zhang, L.; Yue, H.Y.; Zhang, H.J.; Xu, L.; Wu, S.G.; Yan, H.J.; Gong, Y.S.; Qi, G.H. Transport stress in broilers: I. Blood metabolism, glycolytic potential, and meat quality. Poult. Sci. 2009, 88, 2033-2041.

65. Tao, X.; Dong, H.; Zhang, Z.; Xin, H. Daily variation of thyroid hormones in broiler under high-temperature conditions. In Proceedings of the Livestock Environment VII, Beijing, China, 18-20 May 2005; pp. 18-20. 
66. Hosseini, E.; Cheraghi, J.; Taheri, S.S.; Taherpour, K.; Kaviani, K.Z.; Rezazadeh, L. Thyroid hormones investigation under heat stress in broilers administered with probiotic (BIO-SAF) and prebiotic (BIO-MOS). Eur. J. Exp. Biol. 2013, 3, 562-567.

67. Ayo, J.O.; Egbuniwe, I.; Kawu, M.U.; Sinkalu, V.O. Ameliorative effects of betaine and ascorbic acid administration to broiler chickens during the hot-dry season in Zaria: A review. Afr. J. Biotechnol. 2014, 13, 2295-2306.

68. Mack, L.A.; Felver-Gant, J.N.; Dennis, R.L.; Cheng, H.W. Genetic variations alter production and behavioral responses following heat stress in 2 strains of laying hens. Poult. Sci. 2013, 92, 285-294. [CrossRef] [PubMed]

69. Elnagar, S.A.; Scheideler, S.E.; Beck, M.M. Reproductive hormones, hepatic deiodinase messenger ribonucleic acid, and vasoactive intestinal polypeptide-immunoreactive cells in hypothalamus in the heat stress-induced or chemically induced hypothyroid laying hen. Poult. Sci. 2010, 89, 2001-2009. [CrossRef] [PubMed]

70. Star, L.; Decuypere, E.; Parmentier, H.K.; Kemp, B. Effect of single or combined climatic and hygienic stress in four layer lines: 2. Endocrine and oxidative stress responses. Poult. Sci. 2008, 87, 1031-1038. [CrossRef] [PubMed]

71. Bobek, S.; Niezgoda, J.; Pietras, M.; Kacińska, M.; Ewy, Z. The effect of acute cold and warm ambient temperatures on the thyroid hormone concentration in blood plasma, blood supply, and oxygen consumption in Japanese quail. Gen. Comp. Endocrinol. 1980, 40, 201-210. [CrossRef]

72. Mitchell, M.A.; Carlisle, A.J. The effects of chronic exposure to elevated environmental temperature on intestinal morphology and nutrient absorption in the domestic fowl (Gallus domesticus). Comp. Bochem. Physiol. A 1992, 101, 137-142. [CrossRef]

73. Priolo, A.; Micol, D.; Agabriel, J. Effects of grass feeding systems on ruminant meat colour and flavour. A review. Anim. Res. 2001, 50, 185-200. [CrossRef]

74. Cramer, T.A.; Kim, H.W.; Chao, Y.; Wang, W.; Cheng, H.W.; Kim, Y.H.B. Effects of probiotic (Bacillus subtilis) supplementation on meat quality characteristics of breast muscle from broilers exposed to chronic heat stress. Poult. Sci. 2018, 97, 3358-3368. [CrossRef]

75. Sandercock, D.A.; Hunter, R.R.; Nute, G.R.; Mitchell, M.A.; Hocking, P.M. Acute heat stress-induced alterations in blood acid-base status and skeletal muscle membrane integrity in broiler chickens at two ages: Implications for meat quality. Poult. Sci. 2001, 80, 418-425. [CrossRef]

76. Lu, Z.; He, X.; Ma, B.; Zhang, L.; Li, J.; Jiang, Y.; Zhou, G.; Gao, F. Chronic heat stress impairs the quality of breast-muscle meat in broilers by affecting redox status and energy-substance metabolism. J. Agric. Food Chem. 2017, 65, 11251-11258. [CrossRef] [PubMed]

77. Ismail, I.; Joo, S.T. Poultry meat quality in relation to muscle growth and muscle fiber characteristics. Korean J. Food Sci. Anim. Resour. 2017, 37, 873. [PubMed]

78. Warner, R.D.; Ferguson, D.M.; Cottrell, J.J.; Knee, B. Acute stress induced by the preslaughter use of electric prodders causes tougher beef meat. Aust. J. Exp. Agric. 2007, 47, 782-788. [CrossRef]

79. DiGiacomo, K.; Warner, R.D.; Leury, B.J.; Gaughan, J.B.; Dunshea, F.R. Dietary betaine supplementation has energy-sparing effects in feedlot cattle during summer, particularly in those without access to shade. Anim. Prod. Sci. 2014, 54, 450-458. [CrossRef]

80. Feng, J.; Zhang, M.; Zheng, S.; Xie, P.; Ma, A. Effects of high temperature on multiple parameters of broilers in vitro and in vivo. Poult. Sci. 2008, 87, 2133-2139. [CrossRef] [PubMed]

81. Zhang, Z.Y.; Jia, G.Q.; Zuo, J.J.; Zhang, Y.; Lei, J.; Ren, L.; Feng, D.Y. Effects of constant and cyclic heat stress on muscle metabolism and meat quality of broiler breast fillet and thigh meat. Poult. Sci. 2012, 91, 2931-2937. [CrossRef] [PubMed]

82. Fouad, A.M.; Chen, W.; Ruan, D.; Wang, S.; Xia, W.G.; Zheng, C.T. Impact of heat stress on meat, egg quality, immunity and fertility in poultry and nutritional factors that overcome these effects: A review. Int. J. Poult. Sci. 2016, 15, 81.

83. Wang, R.H.; Liang, R.R.; Lin, H.; Zhu, L.X.; Zhang, Y.M.; Mao, Y.W.; Dong, P.C.; Niu, L.B.; Zhang, M.H.; Luo, X. Effect of acute heat stress and slaughter processing on poultry meat quality and postmortem carbohydrate metabolism. Poult. Sci. 2017, 96, 738-746. [CrossRef]

84. Park, S.O.; Kim, W.K. Effects of betaine on biological functions in meat-type ducks exposed to heat stress. Poult. Sci. 2016, 96, 1212-1218. 
85. Zhu, Y.W.; Li, W.X.; Lu, L.; Zhang, L.Y.; Ji, C.; Lin, X.; Liu, H.C.; Odle, J.; Luo, X.G. Impact of maternal heat stress in conjunction with dietary zinc supplementation on hatchability, embryonic development, and growth performance in offspring broilers. Poult. Sci. 2017, 96, 2351-2359. [CrossRef]

86. Gu, X.H.; Li, S.S.; Lin, H. Effects of hot environment and dietary protein level on growth performance and meat quality of broiler chickens. Asian-Australas. J. Anim. Sci. 2008, 21, 1616-1623. [CrossRef]

87. McDonagh, M.; Herd, R.; Richardson, E.; Oddy, V.; Archer, J.; Arthur, P. Meat quality and the calpain system of feedlot steers following a single generation of divergent selection for residual feed intake. Aust. J. Exp. Agric. 2001, 41, 1013-1021. [CrossRef]

88. Frank, D.C.; Geesink, G.; Alvarenga, T.I.R.C.; Polkinghorne, R.; Stark, J.; Lee, M.; Warner, R.D. Impact of high oxygen and vacuum retail ready packaging formats on lamb loin and topside eating quality. Meat Sci. 2017, 123, 126-133. [CrossRef] [PubMed]

89. Azad, K.M.A.; Kikusato, M.; Hoque, A.M.; Toyomizu, M. Effect of chronic heat stress on performance and oxidative damage in different strains of chickens. J. Poult. Sci 2010, 47, 333-337. [CrossRef]

90. Mujahid, A.; Pumford, N.R.; Bottje, W.; Nakagawa, K.; Miyazawa, T.; Akiba, Y.; Toyomizu, M. Mitochondrial oxidative damage in chicken skeletal muscle induced by acute heat stress. J. Poult. Sci 2007, 44, 439-445. [CrossRef]

91. Skrivan, M.; Dlouha, G.; Mašata, O.; Ševčíková, S. Effect of dietary selenium on lipid oxidation, selenium and vitamin E content in the meat of broiler chickens. Czech. J. Anim. Sci. 2008, 53, 306-311. [CrossRef]

(C) 2019 by the authors. Licensee MDPI, Basel, Switzerland. This article is an open access article distributed under the terms and conditions of the Creative Commons Attribution (CC BY) license (http://creativecommons.org/licenses/by/4.0/). 